University of Nebraska - Lincoln

DigitalCommons@University of Nebraska - Lincoln

January 1966

\title{
RELATIONSHIPS AMONG SOME PHYSICAL AND CHEMICAL PARAMETERS OF FULL- VERSUS LIMITED-FED YORKSHIRE PIGS SLAUGHTERED AT DIFFERENT LIVE WEIGHTS
}

\author{
G. M. Babatunde \\ Cornell University \\ W. G. Pond \\ Cornell University \\ L. Dale Van Vleck \\ University of Nebraska-Lincoln, dvan-vleck1@unl.edu \\ G. H. Kroening \\ Washington State University, Pullman \\ J. T. Reid \\ Cornell University \\ See next page for additional authors \\ Follow this and additional works at: https://digitalcommons.unl.edu/animalscifacpub \\ Part of the Animal Sciences Commons
}

Babatunde, G. M.; Pond, W. G.; Van Vleck, L. Dale; Kroening, G. H.; Reid, J. T.; Stouffer, J. R.; and Wellington, G. H., "RELATIONSHIPS AMONG SOME PHYSICAL AND CHEMICAL PARAMETERS OF FULL- VERSUS LIMITED-FED YORKSHIRE PIGS SLAUGHTERED AT DIFFERENT LIVE WEIGHTS" (1966). Faculty Papers and Publications in Animal Science. 323.

https://digitalcommons.unl.edu/animalscifacpub/323

This Article is brought to you for free and open access by the Animal Science Department at DigitalCommons@University of Nebraska - Lincoln. It has been accepted for inclusion in Faculty Papers and Publications in Animal Science by an authorized administrator of DigitalCommons@University of Nebraska - Lincoln. 


\section{Authors}

G. M. Babatunde, W. G. Pond, L. Dale Van Vleck, G. H. Kroening, J. T. Reid, J. R. Stouffer, and G. H. Wellington 
Babatunde, G. M., W. G. Pond, L. D. Van Vleck, G. H. Kroening, J. T. Reid, J. R. Stouffer, and G. H. Wellington. 1966. Relationships among some physical and chemical parameters of full-versus limited-fed Yorkshire pigs slaughtered at different live weights. Journal of Animal Science 25:526-531.

Abstract: An experiment was designed using 30 Yorkshire pigs to study the influence of slaughter weight and feed restriction on carcass cut-out data and to relate these physical measurements to the chemically-determined proximate components. As slaughter weight increased from 79 to 102 $\mathrm{kg}$., the percent of all lean cuts decreased significantly, while that of fat cuts and back-fat thickness increased significantly. Absolute amounts of both fat and lean cuts increased with slaughter weight. Feed restriction significantly increased most of the lean parameters studied and reduced the fat measurements. It increased percent of head and reduced the percent of offal (gastrointestinal tract minus contents, head, respiratory tract and all other internal organs). Correlations between leaf fat and empty body weight and between leaf fat and carcass extractable fat were higher than between back fat and the same parameters. Therefore, leaf fat may be a more satisfactory index of true body fat than is back fat, although the best index still is the carcass extractable fat, for which the correlation with the empty body fat was 0.99 . The offal proximate chemical components were highly correlated with those of the carcass and the empty body. A knowledge of the chemical composition of the offal alone is, therefore, a good reflection of the chemical composition of the empty body. Percent of extractable fat in the empty body, carcass, or offal were positively correlated with fat measures and negatively correlated with all lean measures and with the protein and water. Percents of water and protein were positively correlated with the lean parameters and negatively correlated with all fat characteristics. The saturated fatty acids were positively related to all fat measures and to average daily gain and gross energy of the body and negatively correlated with all lean measures and water and protein. The reverse was true for the unsaturated fatty acids. Also, some strong inverse relationships were found between some unsaturated and saturated fatty acids. The chilled dressing percent was poorly correlated with nearly all physical and chemical measures and, therefore, should not be regarded as a satisfactory index of physical or chemical parameters.

Copyright $\odot 1966$ American Society of Animal Science. Used by permission. 


\title{
RELATIONSHIPS AMONG SOME PHYSICAL AND CHEMICAL PARAMETERS OF FULL- VERSUS LIMITED-FED YORKSHIRE PIGS SLAUGHTERED AT DIFFERENT LIVE WEIGHTS
}

\author{
G. M. Babatunde, W. G. Pond, L. D. VanVleck, G. H. Kroening, ${ }^{1}$ J. T. Reid, \\ J. R. Stouffer and G. H. Wellington ${ }^{2}$ \\ Cornell University, ${ }^{3}$ Ithaca, New York
}

$I^{\mathrm{T}}$ is well established that feed restriction, when imposed at the right stage of growth of the pig, tends to increase the proportion of lean cuts in relation to fat. Most reports have dealt primarily with physical factors such as growth rate, feed efficiency, back-fat thickness, loin-eye area, percent lean cuts and carcass length. Only a few reports (McMeekan and Hammond, 1939; McMeekan, 1940; Zobrisky et al., 1958) have included a more detailed analysis. Similarly, only a few reports (Lu et al., 1958; Zobrisky et al., 1954, 1958; Gnaedinger et al., 1963; Doornenbal, 1961) have described relationships between physical and chemical measurements of the pig.

The purposes of this investigation were to study (1) influences of slaughter weight and feed restriction on physical characteristics of the pig carcass and (2) relationships between physical carcass measures and chemical components of the body.

\section{Experimental}

Thirty closely-related Yorkshire pigs (12 barrows and 18 gilts) were divided into pairs on the bases of sex and ancestry at approximately $45 \mathrm{~kg}$. live weight. One member of each pair was randomly assigned to receive $1.82 \mathrm{~kg}$. of feed daily throughout the experimental period to slaughter at 79,90 or 102 kg., while the other was continued on ad libitum intake throughout. Conventional slaughter procedures were followed. Feed, but not water, was withdrawn approximately 16 hr. prior to slaughter. One-half of each carefully split, dressed carcass was used for conventional physical carcass measurements,

\footnotetext{
1 Present address: Department of Animal Sciences, Washington State University, Pullman.

2 Grateful acknowledgment is given to Mrs. Phyllis Chapman and Earl Walker, Jr., for their help with the chemical analysis and to Joe Powell and Harry Dickson for their help with the care, slaughtering, dressing and grinding of the experimental animals.

${ }^{3}$ Department of Animal Science.
}

while the other half was ground for determination of protein, fat, ash, moisture and gross energy. All other parts (including gastrointestinal tract minus contents, head, respiratory tract and all other internal organs) were pooled, ground and sampled for chemical analysis. These parts are hereafter referred to as "offal". The term "empty body" refers to the whole body minus hair and contents of the intestinal tract. The data were analyzed according to the method of unweighted squares of means for a $2 \times 2 \times 3$ arrangement of factors. Correlations were determined on the pooled data disregarding treatment, sex and weight groups.

\section{Results and Discussion}

Influence of Slaughter Weight on Carcass and Performance Characteristics. Slaughter weight had manifold effects on carcass measurements of the pig (table 1). The lightest pigs had higher proportions of lean cuts than the two heavy groups. A broad generalization in this respect is that lean cuts diminished in proportion as slaughter weight increased, while the fat cuts increased. More specifically, the 79-kg. group had significantly $(\mathrm{P}<.01)$ higher four lean cuts as a percent of chilled carcass weight, ham as a percent of chilled carcass weight, shoulder as a percent of chilled carcass weight and lower back-fat thickness, body length, absolute weight of ham, leaf fat and leaf fat as a percent of empty body, than either of the other two groups. However, when the two heaviest groups were compared, the magnitudes of most of these differences were reduced in many cases. Back-fat thickness and percent lean cuts, ham, shoulder and leaf fat, each as a percent of chilled carcass weight, were not significantly different for the 90 - and $102 \mathrm{~kg}$. groups. Highly significant differences were observed in body length, gross body calories and net calories gained between the two groups; the $102-\mathrm{kg}$. group was favored 
TABLE 1. EFFECTS OF PLANE OF NUTRITION AND SLAUGHTER WEIGHT ON CARCASS QUALITY AND PERFORMANCE CHARACTERISTICS OF YORKSHIRE PIGS

\begin{tabular}{|c|c|c|c|c|c|c|c|c|c|c|}
\hline \multirow[b]{3}{*}{ Items } & \multicolumn{5}{|c|}{ Means } & \multicolumn{4}{|c|}{$F$ value } & \multirow{3}{*}{$\begin{array}{l}\text { Error } \\
\text { mean } \\
\text { squares }\end{array}$} \\
\hline & \multicolumn{3}{|c|}{ Weight group } & \multicolumn{2}{|c|}{ Level of feeding } & \multirow{2}{*}{$\begin{array}{c}\text { Full } \\
\text { vs. } \\
\text { limited }\end{array}$} & \multirow{2}{*}{$\begin{array}{c}79 \mathrm{~kg} . \\
\mathrm{vs} \\
90 \mathrm{~kg} .\end{array}$} & \multirow{2}{*}{$\begin{array}{c}79 \mathrm{~kg} . \\
v \mathrm{~s} . \\
102 \mathrm{~kg} .\end{array}$} & \multirow{2}{*}{$\begin{array}{c}90 \mathrm{~kg} . \\
\text { vs. } \\
102 \mathrm{~kg} .\end{array}$} & \\
\hline & $79 \mathrm{~kg}$ & $90 \mathrm{~kg}$. & $102 \mathrm{~kg}$. & Full & Limited & & & & & \\
\hline Warm dressing percent & 75.1 & 75.3 & 75.6 & 75.3 & 75.4 & * & & ${ }^{*}$ & $\cdots$ & 1.7583 \\
\hline Chilled dressing percent & 73.0 & 73.4 & 73.5 & 73.1 & 73.5 & & & & . & 1.6750 \\
\hline Lean cuts, $\%$ & 57.8 & 54.8 & 54.7 & 54.8 & 56.7 & 13.24 & 20.70 & 22.68 & & 2.0683 \\
\hline Back fat, cm. & 3.3 & 3.8 & 4.0 & 3.9 & 3.4 & 17.85 & 13.19 & 22.35 & 1.04 & 0.1048 \\
\hline Loin eye, cm.2 & 27.5 & 28.0 & 29.6 & 27.4 & 29.3 & 5.08 & & 4.68 & 2.64 & 4.7451 \\
\hline Body length, $\mathrm{cm}$. & 73.7 & 76.7 & 80.0 & 76.5 & 77.1 & 1.56 & 30.64 & 14005 & 38.26 & 1.4278 \\
\hline Daily gain, $\mathrm{kg}$. & 0.64 & 0.59 & 0.64 & 0.77 & 0.50 & 183.08 & 4.93 & & 4.89 & 0.0142 \\
\hline Feed/gain & 3.5 & 3.8 & 3.6 & 3.5 & 3.8 & 5.66 & 4.07 & 1.34 & 10 & 0.1145 \\
\hline Days on feed & 61.9 & 81.4 & 103.7 & 64.0 & 100.6 & 75.30 & 14.47 & 68.95 & 19.54 & 126.68 \\
\hline Cal. consumed/cal, gained & 4.7 & 4.2 & 4.5 & 4.1 & 4.8 & 8.44 & 2.88 & & 1.79 & 0.3587 \\
\hline Gross body energy, therms & 254.0 & 335.3 & 373.7 & 328.6 & 313.4 & 4.56 & 87.76 & 197.92 & 20.30 & $362 \times 10^{6}$ \\
\hline Net energy gained, therms & 155.4 & 236.8 & 275.1 & 230.0 & 214.9 & 4.56 & 87.76 & 197.92 & 20.30 & $362 \times 10^{6}$ \\
\hline G.E./wt.0.7/day/cal. gained, cal.b & 5.94 & 3.44 & 2.46 & 4.30 & 2.87 & & & & & \\
\hline Carcass/empty body wt., o\% & 81,9 & 82.4 & 82.4 & 82.1 & 82.3 & $\cdots$ & 1.52 & 1.88 & . & 0.6778 \\
\hline Offal/empty body wt., \% & 18.1 & 17.6 & 17.6 & 17.8 & 17.7 & & 1.52 & 1.88 & & 0.6777 \\
\hline Ham wt, kg. & 12.7 & 13.9 & 15.7 & 13.8 & 14.4 & 5.58 & 12.07 & 81.32 & 29.94 & 0.5385 \\
\hline $\mathrm{Ham} /$ lean cuts, $\%$ & 38.4 & 37.4 & 38.2 & 38.1 & 38.2 & & & & & 1.8248 \\
\hline $\mathrm{Ham} / \mathrm{chilled}$ carcass wt, $\%$ & 22.2 & 20.8 & 20.8 & 20.9 & 21.7 & 5.52 & 9.80 & 9.47 & . & 0.9517 \\
\hline $\mathrm{Ham} /$ empty body wt., of & 17.7 & 16.7 & 16.7 & 16.7 & 17.4 & 5.04 & 5.88 & 6.30 & & 0.7764 \\
\hline Wt. of head, kg. & 4.7 & 5.2 & 5.9 & 5.1 & 5.4 & 10.15 & 15.26 & 93.91 & 32.55 & 0.0720 \\
\hline Wt. of leaf fat, kg. & 0.9 & 1.3 & 1.7 & 1.3 & 1.3 & $\ldots$ & 12.71 & 44.31 & 9.19 & 0.0715 \\
\hline Empty body wt., kg. & 72.0 & 83.2 & 94.1 & 83.0 & 83.2 & & 217.39 & 876.63 & 211.91 & 2.7761 \\
\hline Loin/lean cuts, \% & 32.4 & 33.7 & 33.4 & 33.4 & 32.9 & 1.09 & 4.88 & 3.26 & $\ldots$ & 1.5338 \\
\hline Loin/chilled carcass wt., $\%$ & 18.7 & 18.4 & 18.2 & 18.3 & 18.7 & 1.87 & ... & 1.85 & $\ldots$ & 0.6726 \\
\hline Loin/empty body wt., \% & 14.9 & 14.8 & 14.6 & 14.6 & 15.0 & 2.42 & . & 1.21 & $\cdots$ & 0.4562 \\
\hline Shoulder/lean cuts, \% & 29 & 28.4 & 28.4 & 28.5 & 28.8 & & 1.80 & 4.63 & $\cdots$ & 1.7653 \\
\hline Shoulder/chilled carcass wt., $\%$ & 16.9 & 15.6 & 15.5 & 15.6 & 16.4 & 6.40 & 11.91 & 14.31 & $\cdots$ & 0.6610 \\
\hline Shoulder/empty body wt., \% & 13.4 & 12.5 & 12.4 & 12.5 & 13.1 & 6.29 & 8.27 & 10.95 & $\ldots$ & 0.4954 \\
\hline Head/empty body wt., \% & 6.5 & 6.2 & 6.3 & 6.2 & 6.5 & 8.11 & 3.52 & 3.43 & & 0.1282 \\
\hline Leaf fat/empty body wt., \% & 1.3 & 1.6 & 1.8 & 1.6 & 1.5 & & 5.83 & 14.89 & 1.95 & 0.1035 \\
\hline Belly/chilled carcass wt., $\%$ & 12.4 & 12.7 & 12.7 & 12.7 & 12.5 & 1.23 & & 1.34 & $\cdots$ & 0.4320 \\
\hline Belly/empty body wt., \% & 9.9 & 10.2 & 10.2 & 10.2 & 10. & & 1.82 & 2.04 & $\ldots$ & 0.2576 \\
\hline
\end{tabular}

${ }^{a} F$ values greater than 4.41 (d.f. 1,18 ) and less than 8.29 (d.f. 1, 18) indicate significant differences at $\mathrm{P}<.05 ;$ those greater than 8.29 at $\mathrm{P}<.01 . F$ values less than 1 are not included in the table.

${ }^{b} F$ values were not calculated for this parameter.

in all cases. Zobrisky et al. (1958) calculated the percent of trimmed ham, loin and shoulder of carcass weight for pigs ranging in weight from 45 to $136 \mathrm{~kg}$. and obtained the same decreasing trend of these lean cuts as the slaughter weight increased.

These results agree fairly well with the findings of Emerson et al. (1964), who found that, as the slaughter weight was lowered from 93 to $45 \mathrm{~kg}$., there was a decrease in carcass length, dressing percent and loin-eye area and an increase in the percent of primal and lean cuts.

Both warm and chilled dressing percents tended to increase with slaughter weight, although the differences between slaughter weight groups were not significant at $\mathrm{P}<.05$. This same tendency for an increase in dressing percent with weight groups was observed by Zobrisky et al. (1958). They obtained significant $(\mathrm{P}<.05)$ differences between 45.5- vs. 68.2-kg. and between $68.2-v s$. $136.4-$ $\mathrm{kg}$. slaughter weight groups, but not between $68.2-$ vs. $90.9-\mathrm{kg}$, nor between $90.9-$ vs. $113.6-$ $\mathrm{kg}$. groups.

With respect to the efficiency of feed conversion expressed in the conventional unit of feed consumed per $\mathrm{kg}$. gain, the 79-kg. group was most efficient and the 90-kg. group was least efficient. When expressed in calories consumed per calorie gained, the $90-\mathrm{kg}$. group was most efficient and the $79-\mathrm{kg}$. group was least efficient. This latter finding is explainable by the fact that the $90-\mathrm{kg}$. group had the highest empty body fat, while the $79-\mathrm{kg}$. group had the lowest body fat. Since fat has approximately 2.25 times the caloric value of carbohydrate or protein, it seems logical although not necessarily true that pigs which had the highest content of fat should be more favored in caloric conversion, provided they did not consume 2.25 times the amount of feed consumed by the lean pigs. When caloric efficiency was expressed in terms of gross calories consumed per weight (kg.0.7) per day per calorie gained, the values obtained were 5.94 , 3.44 and $2.46 \mathrm{cal}$. for the $79-, 90-$ and $102-\mathrm{kg}$. groups, respectively. This further strengthens the argument of higher caloric conversion efficiency of the fatter, heavier pigs than the lighter ones, if the only variable is slaughter weight. Thus, a definite trend for increasing efficiency of caloric utilization could be seen as slaughter weight increased.

Infuence of Feed Restriction on Carcass Characteristics and Caloric Efficiency. Two 
methods were used to express the efficiency of feed conversion: (1) the conventional method of feed per unit of body weight gain, and (2) calories consumed per calorie gained. With either method the full-fed pigs were more efficient than the limited-fed pigs (table 1). These results differ from those reported by Becker (1962) for pigs subjected to the same constant daily intake of $1.82 \mathrm{~kg}$. per head. With respect to caloric conversion it is generally considered that fattening is an expensive and inefficient process. Saint Pierre et al. (1934) noted that, when growing-fattening animals were limited-fed, a longer period was required before they reached the desired market weight and the desired degree of fatness. They interpreted this as evidence that, other factors being constant, restricting feed intake would increase the proportion of feed energy required for body maintenance and, therefore, reduce the proportion available for weight gain. The results of the present investigation agree with this concept, although this was not so when caloric conversion efficiency was expressed in terms of calories consumed per weight per day per calories gained. The figures obtained for this calculation were 4.30 and 2.87 calories for full- and limited-fed pigs, respectively. Here it is clear that, when slaughter weight was equal and the only variable was feed restriction, the pigs on restricted feed intake were more efficient calorie converters than the full-fed pigs (table 1 ).

The full-fed pigs had higher average offal as a percent of empty body weight but lower average carcass and head as percent of empty body weight, but none of these differences was significant. Feed restriction significantly increased amounts of head, shoulder and ham expressed as percent of empty body weight, while it significantly depressed back-fat thickness and net calories gained. The leaf fat and belly expressed as percent of empty body weight were not significantly reduced by feed restriction.

Relationships between Physical and Chemical Measurements. Relationships between the physical fat measurements and the percents of the chemically-determined fat and protein of the empty body, carcass and offal are given in table 2. One relationship often considered is that between certain physical fat measurements, particularly back-fat measurement and the chemically-determined empty body or carcass fat. Back-fat measurement has generally been regarded as the best and most dependable practical index of fatness of pig
TABLE 2. CORRELATIONS BETWEEN PHYSICAL FAT MEASUREMENTS AND CHEMICALLY DETERMINED FAT AND PROTEIN IN PIGS

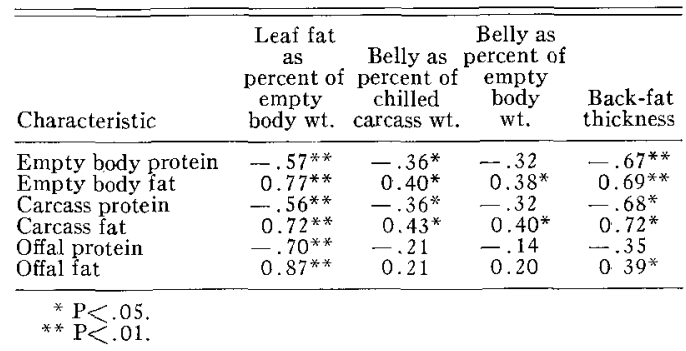

carcasses (Lu et al., 1958). The comparisons appearing in table 2 show that the leaf fat is more highly correlated with extractable fat of the empty body (0.77), carcass (0.72) or offal $(0.87)$ than back-fat thickness with the same parameters $(0.69,0.72$ and 0.39 , respectively) and, therefore, offers an index of true fatness of the animal. However, neither the leaf fat nor back-fat thickness was as good an indication of the true empty body fat as the chemically-determined carcass fat $(r=0.99)$. The close relationship between leaf fat and offal fat resulted, because leaf fat is a component of the offal fraction. Of the three physical fat measurements, the belly showed the lowest correlation with the chemicallydetermined fat.

More detailed relationships between the physical and chemical measurements are given in table 3 . The highly significant negative relationships between fat and water content are especially evident. Although not new, this relationship strengthens the evidence that the process of fattening as the animal ages is essentially one of replacement of water by fat (Lawes and Gilbert, 1861; Moulton, 1923; McMeekan, 1940; Spray and Widdowson, 1951). The strong inverse relationships observed between the chemically-determined fat and protein showed that, while the protein was not actually being replaced by fat during fattening, it showed a relative decrease as the fat increased (Lawes and Gilbert, 1861; Moulton, 1923; Murray, 1922). Water and protein were highly correlated, as was observed by others (Gnaedinger et al., 1963; Doornenbal, 1961).

The relationship between carcass length and other measures of carcass value has received considerable attention. Whereas some investigators (Engleman et al., 1950; Cummings and Winters, 1951) reported a highly significant positive correlation between car- 
TABLE 3. CORRELATIONS ${ }^{a, b}$ BETWEEN SELECTED PHYSICAL AND CHEMICAL MEASURES

\begin{tabular}{|c|c|c|c|c|c|c|c|c|c|}
\hline Item variables & $\begin{array}{l}\text { Empty } \\
\text { body } \\
\text { protein }\end{array}$ & $\begin{array}{c}\text { Empty } \\
\text { body } \\
\text { fat }\end{array}$ & $\begin{array}{c}\text { Empty } \\
\text { body } \\
\text { water }\end{array}$ & $\begin{array}{l}\text { Carcass } \\
\text { protein }\end{array}$ & $\begin{array}{c}\text { Carcass } \\
\text { fat }\end{array}$ & $\begin{array}{c}\text { Carcass } \\
\text { water }\end{array}$ & $\begin{array}{c}\text { Offal } \\
\text { protein }\end{array}$ & $\begin{array}{c}\text { Offal } \\
\text { fat }\end{array}$ & $\begin{array}{c}\text { Gain/ } \\
\text { day }\end{array}$ \\
\hline otei & & -.90 & 0.83 & 00 & -.91 & 0.87 & 0.81 & -.66 & -.50 \\
\hline & -.90 & $\cdots$ & -.97 & -.9 & 0.99 & -.98 & -.77 & 0.84 & 0.21 \\
\hline 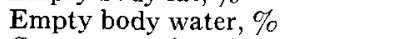 & 0.83 & -.97 & $\ldots$ & 0.81 & -.96 & 0.98 & 0.71 & -.85 & -.09 \\
\hline $\mathrm{Ca}$ & 0.99 & -.89 & 0.81 & 然 & -.91 & 0.85 & 0.75 & -.64 & -.51 \\
\hline Car & -.91 & 0.99 & -.96 & -.91 & & -.98 & --.75 & 0.78 & 0.25 \\
\hline ater, $\%$ & 0.87 & -.98 & 0.98 & 0.85 & -.98 & & 0.75 & -.80 & -.15 \\
\hline,$\%$ & 0.81 & -.77 & 0.71 & 0.75 & -.75 & 0.75 & $\cdots$ & -.73 & -.29 \\
\hline & -.66 & 0.84 & -.85 & -.64 & 0.78 & -.80 & -.73 & & -.01 \\
\hline A & -.67 & 0.69 & -.66 & -.68 & 0.72 & -.68 & -.35 & 0.39 & 0.41 \\
\hline Loi & 0.46 & -.36 & 0.33 & 0.44 & -.42 & 0.41 & 0.37 & -.08 & -.31 \\
\hline $\mathrm{Gr}$ & -.65 & 0.85 & -.88 & -.64 & 0.8 & -.85 & -.57 & 0.86 & 0.06 \\
\hline Ste & 0.43 & 0.26 & -.17 & -.47 & 0 . & -.26 & -.19 & -.08 & 0.49 \\
\hline & -.51 & 0.3 & -.24 & -.44 & 0.31 & -.27 & 0.43 & 0.19 & 0.39 \\
\hline & 0.69 & -.53 & 0.46 & 0.67 & -.54 & 0.52 & 0.70 & -.38 & -.57 \\
\hline id, $\%$ & 0.12 & -.03 & -.04 & 0.15 & -.08 & 0.03 & -.01 & 0.24 & $\ldots$ \\
\hline & 0.13 & 0.01 & -.01 & 0.12 & -.03 & 0.01 & -.07 & 0.15 & -.09 \\
\hline $\mathrm{cm}$. & -.18 & 0.47 & -.55 & -.19 & 0.43 & -.50 & -.29 & 0.58 & -.08 \\
\hline Da & 0.68 & -.74 & 0.71 & 0.71 & -.75 & 0.76 & 0.48 & -.55 & -.31 \\
\hline Loi & 0.46 & -.48 & 0.45 & 0.46 & -.47 & 0.44 & 0.37 & -.37 & -.13 \\
\hline$\%$ & 0.63 & -.68 & 0.68 & 0.64 & -.69 & 0.72 & 0.51 & -.51 & -.23 \\
\hline Bel & -.36 & 0.40 & -.39 & -.36 & 0.43 & -.41 & -.21 & 0.21 & 0.22 \\
\hline $\mathrm{Col}$ & 0.20 & 0.09 & 0.09 & 0.16 & -.11 & & & -.03 & -.11 \\
\hline Percent lean cuts & 0.76 & -.82 & 0.81 & 0.78 & -.84 & 0.84 & 0.59 & -.61 & -.25 \\
\hline
\end{tabular}

a Treatment, sex and weight groups have been disregarded.
b Correlation of $0.36, \mathrm{P}<.05 ; 0.46, \mathrm{P}<.01$.

cass length and percent lean cuts, others (Aunan and Winters, 1949; Zobrisky et al., 1954) found low correlations and Zobrisky et al. (1954) obtained a negative correlation for one breed and a positive correlation for another between these two traits. This investigation showed some anomalous relationships explainable by the fact that the data for sex, treatment and weight groups were pooled for correlation analysis. Since the lightest pigs at slaughter were the shortest and had the thinnest back fat, while the heaviest pigs at slaughter were the longest and had the thickest back fat, length would be expected to be positively correlated with back fat.

The lean cuts as a percent of chilled carcass weight showed highly significant positive relationships with most of the other items of lean meat (table 3 ). This trait was negatively correlated with the fat parameters. These results are in agreement with the observations of Zobrisky et al. (1954) and since confirmed by others (Gnaedinger et al., 1963; Doornenbal, 1961) that the percent of lean cuts is inversely associated with back fat and percent of belly and directly associated with the lean traits.

The relationships between chilled carcass dressing percent and other physical or chemical variables were very low and most were nonsignificant. It has often been argued that fat has a greater effect on, and therefore should have a higher relationship with, chilled dressing percent than with the lean portion of the carcass (Hankins, 1953). Correlations between chilled dressing percent and back-fat thickness, loin-eye area, percent lean cuts, empty body fat and carcass fat were 0.03 , $0.45,0.24,0.09$ and -.11 , respectively. Although except for loin-eye area these relationships are comparatively low, it appears that the chilled carcass dressing percent was more closely related to the lean content of the body, and, therefore, this trait should be influenced more by the lean than by the fat parameters.

Generally, the saturated fatty acids of the back fat were positively related to the extractable fat of the empty body, carcass and offal and to the back-fat thickness and other physical fat measures, while they were negatively correlated with the protein and water of the empty body, carcass and offal and to all lean measures of the carcass. The situation was the reverse with the unsaturated fatty acids, i.e., these were positively correlated with all characteristics of lean and negatively correlated with all fat measurements. Linoleic acid was more highly related, positively or negatively, to most of the physical and chemical measurements than were the saturated fatty acids. From the fairly strong inverse relationships existing between most of the saturated and un- 
saturated fatty acids (table 4), it seems that softening of back fat is a phenomenon accomplished by the gradual replacement of dilution of the already existing saturated fatty acids with the unsaturated ones. Furthermore, it was observed that average daily gain was positively related to saturated fatty acids and negatively to the unsaturated ones. Most of these findings are in agreement with the report of Callow (1935), who claimed that a slowly growing pig usually has a slower rate of fat synthesis and deposition, which in turn is related to a softer back fat.

Finally, an examination of the relationships between chemical constituents of the offal, carcass and the empty body shows that the offal proximate constituents were sufficiently highly correlated with those of the empty body to indicate that a reasonably accurate estimate of the chemical composition of the empty body or of the carcass could be achieved by analyzing the offal.

\section{Summary}

An experiment was designed using 30 Yorkshire pigs to study the influence of slaughter weight and feed restriction on carcass cutout data and to relate these physical measurements to the chemically-determined proximate components. As slaughter weight increased from 79 to $102 \mathrm{~kg}$., the percent of all lean cuts decreased significantly, while that of fat cuts and back-fat thickness increased significantly. Absolute amounts of both fat and lean cuts increased with slaughter weight. Feed restriction significantly increased most of the lean parameters studied and reduced the fat measurements. It increased percent of head and reduced the percent of offal (gastrointestinal tract minus contents, head, respiratory tract and all other internal organs). Correlations between leaf fat and empty body weight and between leaf fat and carcass extractable fat were higher than between back fat and the same parameters. Therefore, leaf

\section{TABLE 4. CORRELATIONS AMONG THE INDIVIDUAL FATTY ACIDS OF THE BACK FAT}

\begin{tabular}{lcccr}
\hline Acids & Palmitoleic & Stearic & Oleic & Linoleic \\
\hline Palmitic & 0.16 & 0.15 & $-.49^{*}$ & $-.44^{*}$ \\
Palmitoleic & $\ldots$ & $-.60^{* *}$ & 0.08 & 0.01 \\
Stearic & $\ldots$ & $\ldots$ & $-.50^{* *}$ & -.31 \\
Oleic & $\ldots$ & $\ldots$ & $\ldots$ & -.26 \\
\hline$* \mathrm{P}<.05$. & & & & \\
$* \mathrm{P}<.01$. & & & &
\end{tabular}

fat may be a more satisfactory index of true body fat than is back fat, although the best index still is the carcass extractable fat, for which the correlation with the empty body fat was 0.99 .

The offal proximate chemical components were highly correlated with those of the carcass and the empty body. A knowledge of the chemical composition of the offal alone is, therefore, a good reflection of the chemical composition of the empty body. Percent of extractable fat in the empty body, carcass, or offal were positively correlated with fat measures and negatively correlated with all lean measures and with the protein and water. Percents of water and protein were positively correlated with the lean parameters and negatively correlated with all fat characteristics. The saturated fatty acids were positively related to all fat measures and to average daily gain and gross energy of the body and negatively correlated with all lean measures and water and protein. The reverse was true for the unsaturated fatty acids. Also, some strong inverse relationships were found between some unsaturated and saturated fatty acids.

The chilled dressing percent was poorly correlated with nearly all physical and chemical measures and, therefore, should not be regarded as a satisfactory index of physical or chemical parameters.

\section{Literature Cited}

Aunan, W. J. and L. M. Winters. 1949. A study of the variations of muscle, fat and bone of swine carcasses. J. Animal Sci. 8:187.

Becker, D. E. 1962. Limited feeding for hogs. Ill. Agr. Exp. Sta., Ill. Res. 4:3.

Callow, E. H. 1935. Carcass quality of the pig in relation to growth and diet. Empire J. Exp. Agr. $3: 80$.

Cummings, J. N. and L. M. Winters. 1951. A study of factors related to carcass yields in swine. Minn. Agr. Exp. Sta. Tech. Bul. 195:32.

Doornenbal, H. 1961. The relationship between $\mathrm{Cr}^{51}$ determined red cell volume and the lean body mass in rats and pigs. Ph.D. Thesis. Cornell University, Ithaca, New York.

Emerson, J. A., A. M. Pearson, J. A. Hoefer, W. T. Magee and L. J. Bratzler. 1964. Effects of slaughter weight upon the processing characteristics, quality and consumer acceptability of pork carcasses and cuts. J. Animal Sci. 23:436.

Engelman, G., A. A. Dowell, E. F. Ferrin and P. A. Anderson. 1950. Marketing slaughter hogs by carcass weight and grade. Minn. Agr. Exp. Sta. Tech. Bul. 187 .

Gnaedinger, R. H., A. M. Pearson, E. P. Reineke and V. M. Hix. 1963. Body composition of market weight pigs. J. Animal Sci. 22:495.

Hankins, O. G. 1953. Physical analysis for determination of carcass fat. Proc. Recip. Meat Conf. 6:131. 
Lawes, J. B. and J. H. Gilbert. 1861. On the composition of oxen, sheep and pigs and of their increase whilst fattening. J. Royal Agr. Soc. England $21: 433$.

Lu, K. H., L. M. Winters, W. J. Aunan and W. E. Rempel. 1958. Estimating the percentage of lean and fat in swine carcasses. Minn. Agr. Exp. Sta. Tech. Bull. 224.

McMeekan, C. P. 1940. Growth and development in pigs with special reference to carcass quality characters. III. Effect of plane of nutrition on form and composition of bacon pig. J. Agr. Sci. 30:511.

McMeekan, C. P. and J. Hammond. 1939. Improvement of carcass quality in pigs. Great Britain J. Ministry Agr. 48:238.

Moulton, C. R. 1923. Age and chemical development of mammals. J. Biol. Chem. 57:79.
Murray, J. A. 1922. The chemical composition of animal bodies. J. Animal Sci. 12:103.

Saint Pierre, J. M., F. B. Morrison and J. P. Willman. 1934. Relative efficiency of limited-and fullfeeding for fattening pigs in dry lot. Proc. Am. Soc. An. Prod. p. 101.

Spray, C. M. and E. M. Widdowson. 1951. The effect of growth and development on the composition of mammals. British J. Nutr. 4:332.

Zobrisky, S. E., J. F. Lasley, D. E. Brady and L. A. Weaver. 1954. Pork carcass evaluation. Mo. Agr. Exp. Sta. Res. Bul. 554.

Zobrisky, S. E., H. D. Naumann, J. F. Lasley, D. E. Brady and A. M. Mullins. 1958. Physical composition of swine during growth and fattening. Mo. Agr. Exp. Sta. Res. Bul. 672. 